\title{
Meet the candidates for ALA president
}

\section{By Ken Dowlin and Ann Symons}

\section{Be sure to vote in the election this spring}

$\mathbf{T}$ he ACRL Board of Directors posed the following questions to each of the candidates for ALA president and CERL News is pleased to publish their responses. Each candidate was given 1,200 words in which to offer a brief opening statement and to respond to the questions; their responses are identified under each of the six questions.

\section{Ken Dowlin}

I have worked as director of four library systems, as a consultant to libraries in the U.S. and abroad, a consultant with technology-based corporations, and as an adjunct professor in one community college and two universities. Having started my career as a bookmobile driver and working my way up to director of one of the major libraries in the country, I understand the business extremely well.

Having been president of LITA when the operating agreement was being contemplated ensures that I understand the issues that concern divisions. I also know the workings of ALA as a whole having served as chair of the ALA Awards Committee, and as a member of the ALA Council, the Planning and Budget Assembly, the ALA President's Committee on Preservation Policy, and the ALA President's Commission on Freedom and Equity of Access to Information. Serving on other national bodies such as the Library of Congress Commission of the Future of the Book and the LC/ALA task force on the Marketing of the MARC record has given me an even broader perspective.

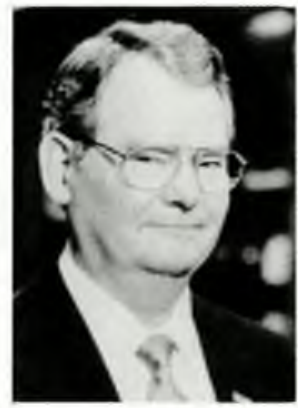

Ken Dowlin

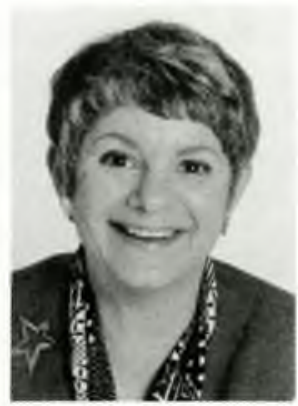

Ann Symons
I also have extensive knowledge of the interests of chapters and regional organizations having served as president of the Colorado Library Association, president of the Board of the Bibliographical Center of Research, a member of various committees of the Mountain Plains Library Association, and as chair of the Technology Committee for the Western Interstate Commission on Education. In California, I founded the Greater Bay Area Library Council, serve on the Resource Libraries Task Force of the California State Networking Committee, and was a charter member of the Board of the Bay Area Book Festival.

Author of the book The Electronic Library: The Promise and the Process, I have published more than 80 articles, contributions to books, and papers. I have also produced a series of videotapes on the use of library technology. I am a noted speaker on technology and library issues, having made presentations in most of the states and eight different countries.

I hold an MLS from the University of Den ver, a master's degree in public administration from the University of Colorado, and a bachelor's degree in history from the University of Colorado. 


\section{Ann Symons}

I started my career as an academic librarian. When I came to Alaska there were no academic jobs so I took a position as a school librarian and promptly began to work with academic and public librarians to expand services to all our users.

Just as I worked cooperatively at home in Alaska, I've worked cooperatively with ACRL members for more than a decade-on Council, on ALA's Executive Board, as your treasurer, and now as chair of ALA's Intellectual Freedom Committee. I look forward to continuing our teamwork. I understand the association, its values, its power for advancing our information and service agenda, and its members' needs. I believe these are important traits for an ALA president. Working together I know we can achieve our goals.

\section{Questions for ALA candidates}

1. What is your position on the acceptability of ALA divisions, such as ACRL, to establish and publicly promulgate their own positions on issues important to the profession and germane to their own interests? Should divisions be encouraged to establish relationships, independent of ALA, with relevant organizations, such as AAHE, for example?

Dowlin: It is important for ALA to develop as an organization that values the diversity of not only its members but its divisions and chapters. The relationship among all of the units must be organic in nature, not cast in stone. I was president of LITA at the inception of the Operating Agreement and I feel that ALA becoming more of a confederation and less centric has been a big factor in membership growth and the effectiveness of the association. Divisions should be encouraged to develop collaboration where it is in the interest of all parties. ALA must respect that need. At the same time, the divisions need to communicate with ALA leadership on goals and programs. There are issues that can be resolved or advanced only with the full participation of all of the divisions, chapters, and other units.

Symons: ALA needs the expertise of ACRL on issues of importance to academic librarianship and should actively encourage the division to take leadership on those issues. At the same time, ACRL should use the clout of ALA and its 57,000 members when advocating its position or supporting policy issues of impor- tance to academic libraries. One of ACRL's goals is to collaborate with other professional organizations and associations of higher education. ACRL was recently invited to participate in a national initiative on faculty roles and rewards. This is an example of the kind of partnership that is essential for ACRL to do its work and it raises the credibility of ACRL and ALA. I would actively encourage and support such efforts as ALA president. The work you do with outside organizations benefits all of us.

2. The activities of the ALA Washington Office have focused primarily on matters of concern to public libraries. What would you do to expand the office's activities to deal with issues of concern to academic libraries?

Dowlin: For the past several years the ALA Washington Office has worked hard on the successful revision of LSCA and telecommunications cost issues. On the other hand, having been on the ALA Legislation Committee I can tell you that the Office in Washington is usually juggling several dozen issues. The increase in the budget and the facilities has paid off handsomely for the public libraries and I would propose that it is time to focus on the needs of other libraries. The program developed by ACRL for the legislative and regulatory agenda should now become a priority. It is critical to have representation from all the divisions in legislative matters and even though the Legislation Assembly is charged with that responsibility there is more work to be done

Symons: The Washington Office works on many issues of major significance to academic libraries. Most recently, the ALA Washington Office was able to represent ACRL's interests in Geneva at the WIPO Treaty Meeting on copyright, intellectual property, and databases. Jim Neal, ALA Executive Board member and an academic librarian, was ALA's member representative.

The Washington Office currently is involved with intellectual property and copyright legislation, the Digital Futures Coalition, Internet II, intellectual freedom issues such as the Communications Decency Act, and access to government information. These are all viewed as issues of concern primarily to academic librarians. The ALA Washington Office fought for the inclusion of academic libraries in the universal service provisions of the Telecommunications Act of 1996 
The Washington Office calls upon ACRL when setting its agenda and priorities when it is aware of an ACRL interest. ACRL members need to be proactive in bringing to the attention of the Washington Office and the Legislative Committee those issues that deal with their concerns without waiting to be asked. The important thing is that we work in concert on information policies that move the national library agenda forward. ACRL's contribution to ALA Goal 2000 is an example of how we can leverage our resources to accomplish these goals. I look forward to working with you and others on these endeavors.

\section{A strong ALA with a centralized focus} provides great strength to the profession. However, ALA is made up of 11 divisions. What should be the appropriate input from the divisions to ALA in influencing policy and procedure?

Dowlin: The divisions should be full partners with the other units within ALA and the leadership of the association. It is important for them to be represented on Council and ALA committees. The divisions should have ample opportunity to propose and react to policies and programs even if it means delaying the decisions to allow time for consideration. It is my concern for the future of librarianship that has led me to devote the rest of my career to ensuring its vitality and continuance.

Symons: My sense of ALA is that when members of ACRL and other divisions speak, Council and the Executive Board listen carefully. ACRL lends great strength to the association. When higher education is involved, ACRL should be the first place we turn. Nobody else has the expertise and the strength of membership that ACRL has on these issues. ALA needs to turn to all of its divisions for issues on which they have membership expertise and responsibility. Division presidents and president-elects have opportunities to meet with each other to put forward and influence policy and procedures. Divisions do not always agree on every issue and then hard choices have to be made; however, when they do agree, their voice is very strong.

4. The ALA Annual Conference continues to grow in size and complexity; there is concern about program overlap, the number of governance meetings, discussion groups sponsoring programs, and the cost of providing high-end computing and audiovisual support for programs. As ALA president for a year, and an ALA Board member for three years, what actions will you take to streamline ALA national conferences? Should programs developed by units of ALA go through a competitive process for selection?

Dowlin: I would not like for the programs and events at the conferences to be dictated from the president, the Executive Board, or Council. Our strength is in our diversity and the ability for any member to become involved in a committee, a program, or a task force that interests them. While we complain about the multitude of programs and committee meetings at conferences, $I$ feel it is our strength. The key to avoiding overlaps is better communication for the scheduling and sharing of themes. Since most of the talent for our programs comes from our own members there is not a significant cost for redundancy. In terms of the cost of high-end computer and audiovisual support, I find that the more enlightened convention centers provide full Internet access and projection as a matter of course. ALA should negotiate for the support needed as a prerequisite for the site. The Conference Program Procedures and Policies Review Committee is charged with creating the database of the programs, developing timelines that allow the coordination of schedules, and submitting improvements for the conferences to the Planning Committee, and ACRL should forward any concerns it has to the committee.

Symons: ALA's conferences offer something for everybody. You either always go and are proud to have never missed a year, go when it is near your home, or never go and save your money for the fantastic division conferences, like ACRL in Nashville. Our members have many choices and go to conference for many different reasons. We must make ALA's conferences responsive to the needs of our members, our exhibitors, and our agenda. The newly formed ALA Conference Committee is bringing together a knowledgeable group of members to address these problems on an ongoing basis. This committee will be seeking suggestions and recommendations from divisions and will listen carefully. As your president I will appoint to this committee the best people I can find and I will act on their recommendations. Members of ACRL will be among the first I will look for to serve on this group. 
5. As we move inevitably into the electronic information age where information can be obtained increasingly without a librarian intermediary, what are your views on the future of librarianship or roles future libraries will play in the information society?

Dowlin: Public opinion polls, local referendums, and bond issues all over show that libraries are among the most respected institutions in their communities. As long as libraries retain the trust and respect of the people their future is assured. I am not so confident about the future of librarians and librarianship. This is the primary reason that I am running for president of ALA. We must create the "Vision of Librarianship" for the 21st century, enlist the support to implement that vision, and develop the education program to ensure librarians and library leaders for the future. The education program must not teach only the skills and the methodology of librarianship, it must teach the values, the professionalism, the networking, and the commitment to service that has characterized the profession for at least a half century.

Symons: The world of libraries is changing rapidly. I can sit in my library in an isolated small town in Alaska and find information from around the globe. My job has changed. Our mission as a profession has not changed. We have always connected people and information and we have always been about education and the management of knowledge. We represent the public's information interest.

Technology is not an end in itself. It is a tool to provide access. It will not eliminate the essential librarian's role. There will always be a need for librarians: as teachers, collaborators with faculty, organizers, navigators, managers, locators, and creators of information. These are things we've always done but now we'll do them in new ways. There will always be a place in our schools and on our campuses for librarians to teach critical thinking and information skills. The 21 st century will be about how the technology is used to increase access. Librarians will have a major role to play in ensuring that this happens and that there is fair and equitable access to information for all segments of our communities.

6. It is sometimes argued that in the legal, medical, and engineering fields, pro- fessional certification has led to consistent standards of practice and raised the esteem (and pay) of the practitioners in those professions. Should ALA support certification of librarians as having a defined set of skills and body of knowledge? Should ALA be the certifying agency? Why or why not?

Dowlin: I personally believe in certification as a process to distinguish different levels of skills and experience. As president of the Colorado Library Association (CLA) I worked for certification by the state of Colorado. It didn't succeed because the members of CLA couldn't agree on its importance. I doubt that the political climate is such that legislation could be passed at the state or national level now. I would like for ALA, with the divisions, to pursue voluntary certification like exists in a number of fields such as real estate, financial advisors, and health care. My wife is a certified clinical laboratory manager in addition to her state and federal certification as a clinical laboratory scientist. ALA should take the lead.

Symons: Continuing education is important to ALA's members. We are experiencing a dramatic change in libraries and we all agree that librarians need to commit to continual learning and the constantly developing new skills we need to serve our communities. The question is whether certification is needed to force this commitment to ensure we achieve our educational goals. There is no consensus about this yet.

Both ACRL and AASL (the American Association of School Libraries) have explored the idea of certification. There is currently a LAMA PLA proposal for a post-MLS certificate program in public library administration which has been approved by the LAMA and PLA Boards.

Certification, however, is no guarantee of quality. There are many questions to asklegal questions, questions about quality and content, and questions about ALA's role versus the role of state library associations, our divisions, and other library organizations providing continuing education. There are also questions about whether building the necessary bureaucratic infrastructure would be worth the results. Certification requires that we can specify the specific skills needed. Given the dynamic nature of the environment, this will be a challenge. As president of ALA, I would provide a forum for a professional dialogue on this topic and would commit to initiating the actions that result. 


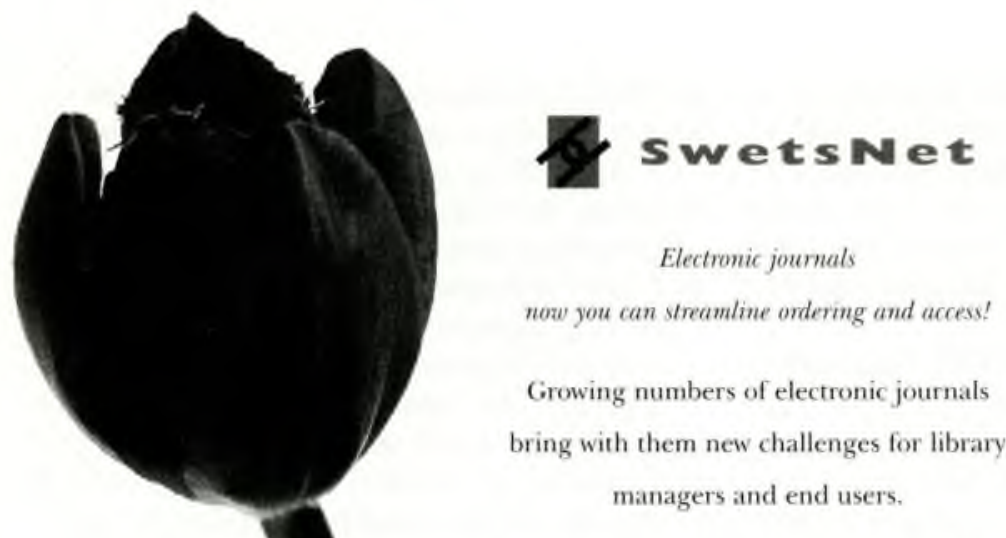

SwetsNet is a major new service, providing a single source for accessing a broad range of publishers' electronic titles.

SwetsNet offers:

- browsing of contents of specific joumal issues

- full searching across all titles in

Swets Net or those subscribed to by your library
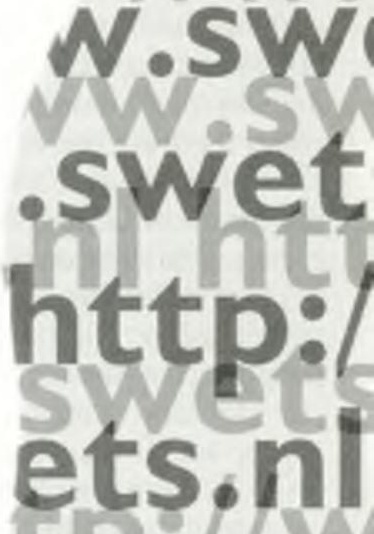
1
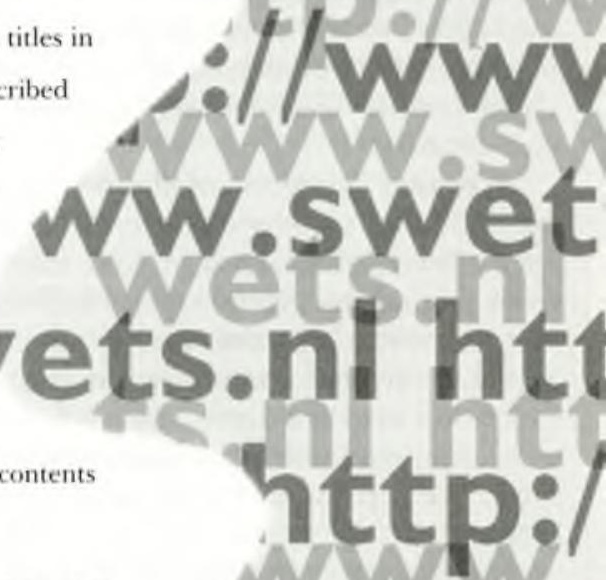

- searching of tables of contents and abstracts

- regular management information

- full information and support services

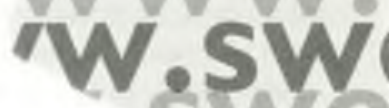

- simplified password administration

- Swets Net is accessible via the WWW

See a demonstration of SwetsNet in booth \#602 at the ACRL National Conference
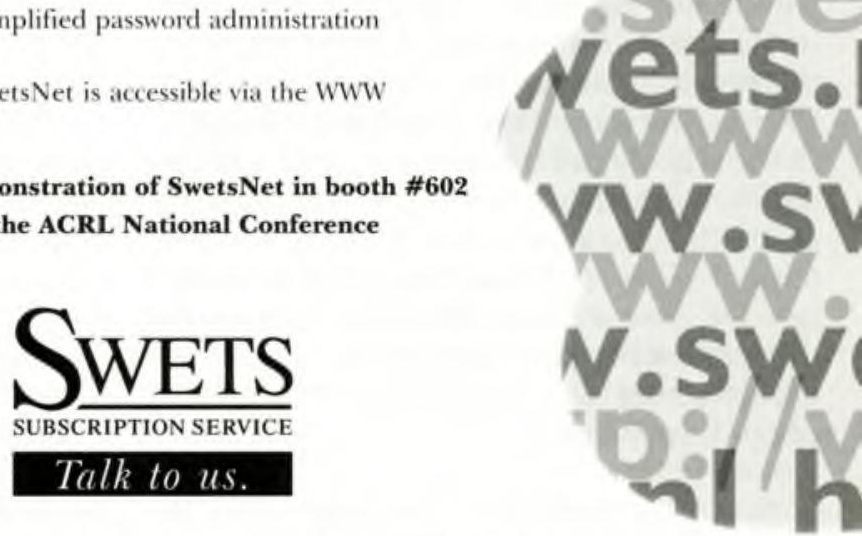

Swets Subscription Service - 440 Creamery Way, Suite A - Exton, PA 19341 - Tel: 800-447-9387 • Fax: 610-524-5366 